\title{
Hf-Nd Isotopes in Archean Marine Chemical Sediments: Implications for the Geodynamical History of Early Earth and Its Impact on Earliest Marine Habitats
}

\author{
Sebastian Viehmann ${ }^{(1)}$ \\ Department of Geodynamics and Sedimentology, University of Vienna, Althanstraße 14, Vienna 1090, Austria; \\ sebastian.viehmann@univie.ac.at; Tel.: +43-1-4277-53680
}

Received: 30 May 2018; Accepted: 9 July 2018; Published: 16 July 2018

\begin{abstract}
The Hf-Nd isotope systems are coupled in magmatic systems, but incongruent Hf weathering ('zircon effect') of the continental crust leads to a decoupling of the Hf-Nd isotope systems in low-temperature environments during weathering and erosion processes. The Hf-Nd isotope record was recently dated back from the Cenozoic oceans until the Archean, showing that both isotope systems were already decoupled in seawater $2.7 \mathrm{Ga}$ ago and potentially $3.4 \mathrm{Ga}$ and $3.7 \mathrm{Ga}$ ago. While there might have existed a hydrothermal pathway for Hf into Archean seawater, incongruent Hf weathering of more evolved, zircon-bearing uppermost continental crust that was emerged and available for subaerial weathering accounts for a significant decoupling of Hf-Nd isotopes in the dissolved $(<0.2 \mu \mathrm{m})$ and suspended $(>0.2 \mu \mathrm{m})$ fractions of Early Earth's seawater. These findings contradict the consensus that uppermost Archean continental crust was (ultra)mafic in composition and predominantly submerged. Hence, Hf-Nd isotopes in Archean marine chemical sediments provide the unique potential for future research to trace the emergence of evolved continental crust, which in turn has major implications for the geodynamical evolution of Early Earth and the nutrient flux into the earliest marine habitats on Earth.
\end{abstract}

Keywords: Hf-Nd isotopes; Archean; seawater; zircon effect; Hf-Nd decoupling; incongruent weathering; emergence of continents; early life

\section{Introduction}

The geodynamical evolution of the Archean Earth is one of the most debated research topics in geosciences in the last decades. Studies from several different fields in geosciences have tackled the formation of the first continents to investigate the interplay between Earth's mantle and crust. The composition of the uppermost Archean continental crust is believed to be more mafic-ultramafic relative to its post-Archean counterparts and relative to modern uppermost continental crust that is overall felsic in composition, e.g., [1]. However, TTGs (tonalite-trondhejmitic gneisses) were already present in the middle to lower levels of the earliest continental crust constituting remnants of the earliest felsic continental crust [2,3]. TTGs were produced either by melting of hydrated basaltic material that was brought in deeper crustal levels via subduction-style processes or by non-subduction style processes such as vertical growth of oceanic plateaus above mantle plumes ([2,4], and references therein). Stacked flood basalts and oceanic plateaus that were produced during times of high magmatic activity shaped the uppermost continental crust [1]. Hence, the earliest Archean continents had a high(er) density and due to relative lower buoyancy, most of the earliest landmasses were submerged and were therefore not available for subaerial weathering. Flament et al. [5] calculated that only $2-3 \%$ of Archean continents were emerged until the Late Archean, while Kamber [6] showed that 
predominant chemical weathering of (ultra)mafic upper continental crust is needed to explain the typical trace element signatures of Archean marine chemical sediments. However, the timing of the emergence of more evolved upper continental crust that was available for subsequent subaerial weathering and erosion processes during Archean times is highly uncertain. Large et al. [7] showed with a comprehensive trace element study of Precambrian shales that the composition of the uppermost continental crust changed from predominantly ultramafic-mafic to more felsic at around $2.7 \mathrm{Ga}$ ago. Viehmann et al. [8,9] applied a novel geochemical approach using combined $\mathrm{Hf}$ and $\mathrm{Nd}$ isotopes in Late Archean marine chemical sediments to investigate weathering and erosion processes on Archean continents and their impact on Archean seawater chemistry. The authors showed that similar to modern oceans, $\mathrm{Hf}$ and $\mathrm{Nd}$ isotope systems were already decoupled in the suspended $(>0.2 \mu \mathrm{m})$ and dissolved $(<0.2 \mu \mathrm{m})$ fractions of Late Archean seawater. Decoupled Hf-Nd isotopes in Banded Iron Formations (BIFs) indicate that incongruent Hf weathering and erosion of more evolved, zircon-bearing continental crust already occurred $2.7 \mathrm{Ga}$ ago $[8,9]$. These findings in combination have major implications on the geodynamical evolution of the Archean continents and, of course, on the nutrient flux derived from the continents into the earliest marine habitats on Earth. However, clastic sediments in worldwide-distributed greenstone belt successions, e.g., [10-12], indicate that at least parts of more evolved continental crust were already subaerial weathered and eroded during the Meso- and Paleoarchean, potentially uplifted by gravitational overturn of felsic proto-crust [13]. The urgent scientific questions remain to which amount and when evolved continental crust was available for chemical weathering and erosion processes to affect Archean seawater chemistry and the coincident flux of (bio)available nutrients into the earliest marine habitats on Earth.

In this review, an overview of the state of the art Hf-Nd isotope geochemistry in modern and ancient low-temperature environments is given. It describes the potential of these combined isotope systems to investigate the geodynamical evolution of the Archean Earth and the impact of enhanced weathering on ancient marine environments and the interplay between the earliest continents, oceans and biosphere.

\section{Hf-Nd Isotopes in Modern to Cenozoic Aqueous Environments}

\subsection{Decoupling of Hf-Nd Isotopes in Seawater}

The Hf and $\mathrm{Nd}$ isotope systems are coupled in magmatic systems and are powerful geochemical proxies in high-temperature regimes to investigate the interplay of Earth's mantle and crust, i.e., to resolve magma differentiation, fractional crystallization, and recycling processes (e.g., [14-16]). Both isotope systems are radioactive isotope systems, i.e., the mother isotopes ${ }^{147} \mathrm{Sm}$ and ${ }^{176} \mathrm{Lu}$ decay to their daughter isotopes ${ }^{143} \mathrm{Nd}$ and ${ }^{176} \mathrm{Hf}$ with a half-life of $106 \mathrm{Ga}$ and $37.2 \mathrm{Ga}$, respectively, and allow precisely dating of igneous and metamorphic mineral and rock assemblages. Samarium and Lu are more incompatible relative to $\mathrm{Nd}$ and $\mathrm{Hf}$ during partial melting processes, resulting in enrichment of $\mathrm{Sm}$ and $\mathrm{Lu}$ in the Earth's mantle and of $\mathrm{Nd}$ and $\mathrm{Hf}$ in the melt and eventually in the continental crust. This coupled behaviour is expressed in a diagram of $\varepsilon \mathrm{Hf}_{(t)}$ versus $\varepsilon \mathrm{Nd}_{(\mathrm{t})}$ (epsilon notation: measured isotope ratios relative to a reference material and multiplied by 10,000 at a certain time) in which all terrestrial rocks define a linear trend ('terrestrial array' after [17]; Figure 1). In low-temperature environments, however, the situation is more complicated and both isotope systems can be decoupled during weathering and erosion processes. While $\mathrm{Nd}$ isotope data of seawater already existed from the 1980s [18], very low Hf concentrations in seawater (<1 pmol/kg [19]) and the combined analytical difficulties to directly measure Hf isotopes in aqueous media initially prohibited direct Hf isotope measurements. Hence, the earliest studies targeting Hf-Nd isotope behaviour in seawater are derived from marine chemical sediments, i.e., Fe-Mn crusts and nodules that scavenged $\mathrm{Hf}$ and $\mathrm{Nd}$ on $\mathrm{Fe}-\mathrm{Mn}(\mathrm{oxy})$ hydroxide surfaces and served as archives for both geochemical proxies in modern to Cenozoic seawater [20-22]. Fe-Mn crusts and nodules reveal a decoupling of the Hf-Nd isotope systems [21,22], showing more positive $\varepsilon \mathrm{Hf}_{(\mathrm{t})}$ values at given $\varepsilon \mathrm{Nd}_{(\mathrm{t})}$ relative to mantle-derived rocks 
and constitute an own linear trend ('seawater array' after [21]; Figure 1). With the improvement of analytical technology and isotope tracers, the first direct Hf isotope measurements of seawater were conducted $[19,23,24]$ and corroborated the Hf-Nd isotope decoupling in seawater. Although modern seawater data confirm the Hf-Nd isotope decoupling of Fe-Mn crusts and nodules, the $\varepsilon \mathrm{Hf}_{\text {today }}$ values in seawater are more heterogeneous and scatter around the 'seawater array'.

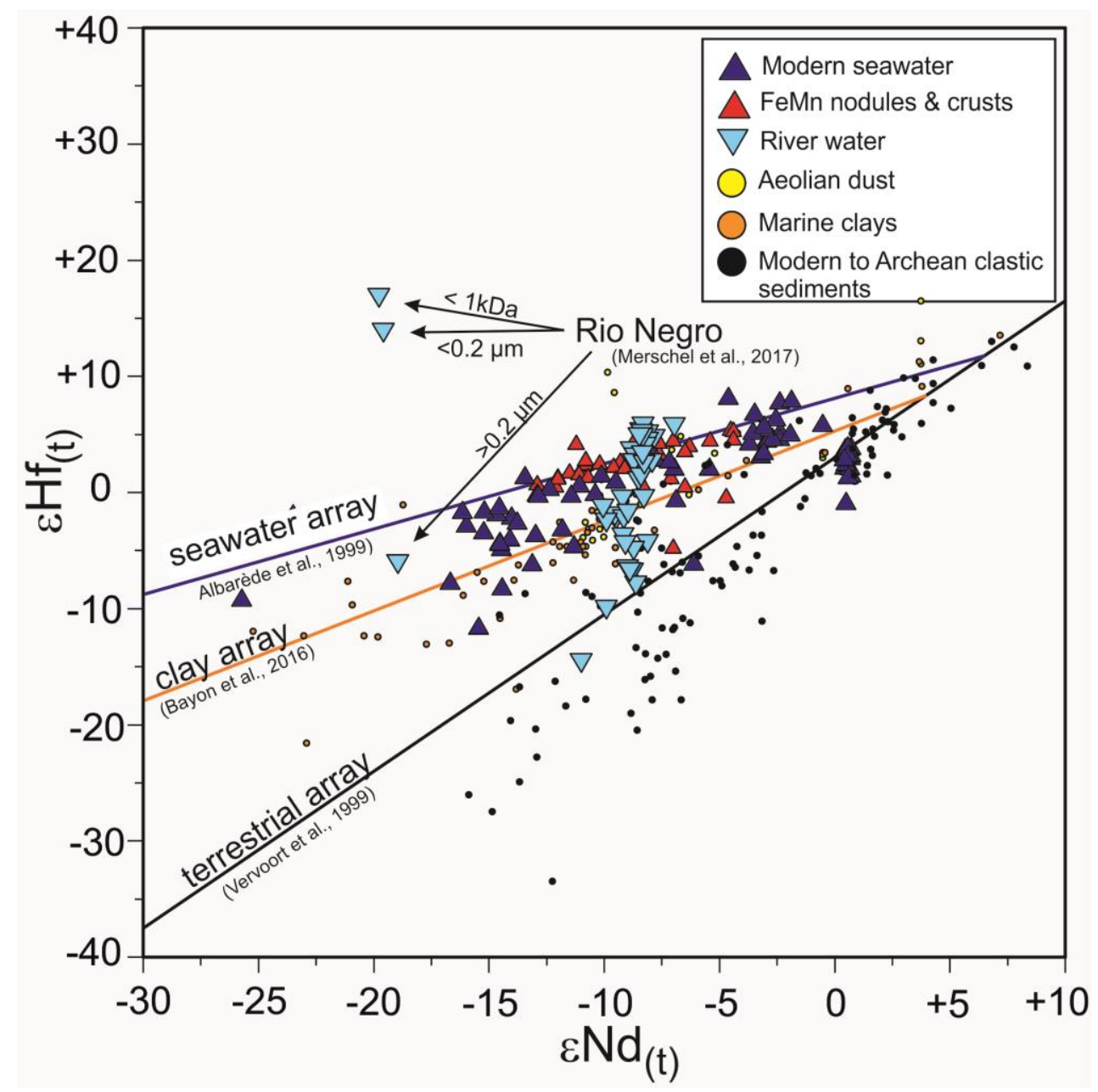

Figure 1. The seawater, clay, and terrestrial arrays relative to initial $\varepsilon \mathrm{Nd}_{(\mathrm{t})}$ and $\varepsilon \mathrm{Hf}_{(\mathrm{t})}$ values of modern seawater (epsilon notation: measured isotope ratios relative to a reference material and multiplied by 10,000 at a certain time), Fe-Mn nodules and crusts, river water, aeolian dust, marine clays, and terrestrial clastic sediments. The Hf-Nd isotope systems are coupled in magmatic systems ('terrestrial array'), but are decoupled in low-temperature environments due to incongruent Hf weathering of the continental crust. Mineral sorting between fine-grained ('clay array') and coarse-grained mineral fractions in the suspended loads of rivers and oceans and during aeolian processes decouple both isotope systems. $\varepsilon \mathrm{Nd}_{(\mathrm{t})}$ and $\varepsilon \mathrm{Hf}_{(\mathrm{t})}$ values are also decoupled in the dissolved fractions of seawater ('seawater array') and river water. Note the filter-size-dependent decoupling of $\varepsilon \mathrm{Nd}_{(\mathrm{t})}$ and $\varepsilon \mathrm{Hf}_{(\mathrm{t})}$ values in Rio Negro water. Data are taken from [17,19,21,23-31].

\subsection{Causes to Decouple Hf and Nd Isotopes in Modern Environments}

\subsubsection{Hf-Nd Decoupling on the Continents}

Patchett et al. [32] observed a decoupling of the Hf-Nd isotope systems in Earth's sedimentary system and introduced the term 'zircon effect' as responsible mechanism to decouple both isotope systems in coarse-grained and fine-grained clastic sediments. The 'zircon effect' describes incongruent 
Hf weathering of the continental crust, i.e., the retention of unradiogenic Hf in zircons during weathering and erosion processes. Hafnium readily substitutes for its geochemical twin $\mathrm{Zr}$ in zircons $\left(\mathrm{ZrSiO}_{4}\right)$ during magmatic processes, which results in relatively low $\mathrm{Lu} / \mathrm{Hf}$ ratios of zircons with respect to the surrounding mineral assemblage. The partition coefficients $\left(K_{d}\right)$ for $S m$ and $N d$ between melt and minerals are almost similar and no significant mineral-dependent $\mathrm{Nd}$ fractionation can be observed (for a recent opposing view see $[33,34]$ ) allowing the use of $\mathrm{Nd}$ isotopes as reliable provenance tracer in clastic sediments. In contrast, the $\mathrm{K}_{\mathrm{d}}$ for $\mathrm{Lu}$ and $\mathrm{Hf}$ between melt and different mineral phases shows a significantly higher variability (Figure 2). Accessory minerals such as apatite and sphene or carbonates with very high $\mathrm{Lu} / \mathrm{Hf}$ ratios are easily weathered during chemical weathering, while zircons and other weathering-resistant minerals with lower $\mathrm{Lu} / \mathrm{Hf}$ ratios remain intact (Figure 2). The incongruent $\mathrm{Hf}$ weathering then results in more radiogenic $\mathrm{Hf}$ isotope compositions of the fluids relative to the bulk weathered material and the remaining unweathered hinterland.

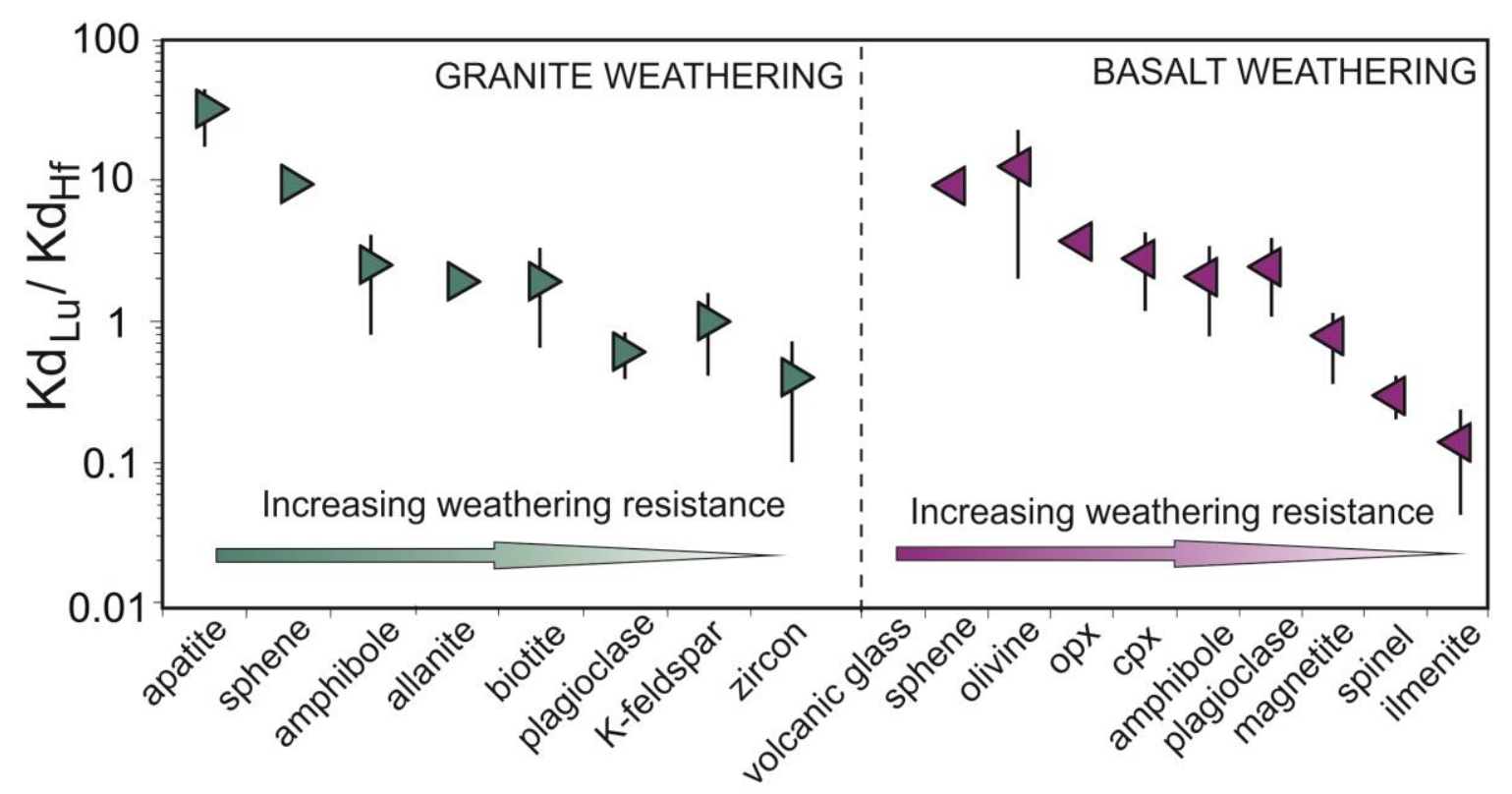

Figure 2. Partition coefficients $\left(\mathrm{K}_{\mathrm{d}}\right)$ for Lu and Hf between melt and minerals in granitic and basaltic systems sorted after weathering resistance of individual minerals (adapted and slightly modified from [29]).

Incongruent $\mathrm{Hf}$ weathering and the decoupling of the Hf-Nd isotope systems due to the 'zircon effect' is less effective during glacial intervals. Either intense glacial mineral grinding and more congruent weathering [35] or longer water-rock interaction time during glacial intervals are suggested to be the responsible for less pronounced Hf-Nd isotope decoupling [36] in seawater. During non-glacial intervals, however, it was shown that trapping of unradiogenic Hf in zircons accounts for $70 \%$ up to $99 \%$ of the Hf-Nd decoupling on the continental hinterland to reproduce the seawater array by only weathering and erosion processes [22,27]. In contrast, Chen et al. [37] modelled that incongruent $\mathrm{Hf}$ weathering of the modern continental crust is insufficient to generate the radiogenic Hf isotopic signature of the 'seawater array'. The model predicts that incongruent $\mathrm{Hf}$ weathering only resembles the Hf-Nd isotope compositions of the clay array, i.e., the zircon-free array, and implies that an additional source has to contribute radiogenic Hf to the modern oceans. Although less pronounced, Hf-Nd isotope decoupling can also be produced by weathering of exclusively basaltic material during preferential weathering of titanite, sphene, and olivine with higher Lu/Hf ratios relative to more weathering resistant minerals such as spinel, ilmenite, pyroxenes, amphiboles, and feldspars with lower Lu/Hf ratios (Figure 2) [29]. 
Different climate conditions also affect incongruent weathering of the continental hinterland: The $\varepsilon \mathrm{Hf}_{(\mathrm{t})}$ values in fine grained shales and waters correlate with the chemical index of alteration, annual temperatures, rainfall, and local discharge rates [27,29], which has strong impact on incongruent Hf weathering, in particular in warm and humid regions. Merschel et al. [31] showed for suspended $(>0.2 \mu \mathrm{m})$, dissolved $(<0.2 \mu \mathrm{m}$; truly dissolved plus colloidal fraction), and truly dissolved $(<1 \mathrm{kDa})$ water fractions of the Amazonas contributories Rio Solimoes and Rio Negro that $\varepsilon \mathrm{Hf}_{\text {today }}$ values increase with decreasing abundance of zircon fragments (Figure 1). The $\varepsilon \mathrm{Hf}_{\text {today }}$ values in the dissolved and truly dissolved loads of the Rio Negro are more positive relative to the seawater array due to lowered erosion and increased chemical weathering rates in tropical lowland soils [31]. In contrast, the $\varepsilon \mathrm{Hf}_{\text {today }}$ values in suspended and dissolved fractions of the Rio Solimoes are less positive relative to the Rio Negro, because the Hf inventory is solely controlled by mineral sorting processes and dominated by Andean highland input with inverse erosion and chemical weathering rates [31]. Mineral sorting processes of 'heavy' sand-sized fractions (including zircons) and fine grained, zircon-poor fractions are also observed during aeolian processes [21,25] and in other rivers [33,38]. Hydrodynamical and aeolian mineral sorting processes decouple $\mathrm{Hf}$ and $\mathrm{Nd}$ isotopes in very fine grained sediments (Figure 1) during sediment transport, resulting in $\varepsilon \mathrm{Hf}_{(t)}$ and $\varepsilon \mathrm{Nd}_{(\mathrm{t})}$ values that plot close to the seawater array [25], while zircon-rich fractions plot slightly below the terrestrial array, e.g., [39].

\subsubsection{Hf-Nd Decoupling in Seawater}

Hafnium and the rare earth elements (REE; including $\mathrm{Sm}, \mathrm{Nd}$, and $\mathrm{Lu}$ ) are particle-reactive elements and their residence times in seawater are smaller than the water mixing time of ca. 1500 years [40], which is needed to homogenize the elemental concentrations and their isotope compositions in modern oceans. The residence time of $\mathrm{Nd}$ in modern seawater is suggested to be between 360 and 700 years [41,42]. Although earlier studies prefer a conservative behaviour of Hf in seawater [20,43], it is nowadays accepted that Hf is scavenged more efficiently in surface water relative to $\mathrm{Nd}$ [44], resulting in a residence time of $\mathrm{Hf}$ below few 100 years [19,23]. The residence time of $\mathrm{Hf}$ in intermediate and deeper waters is longer than that of $\mathrm{Nd}$ and increases to 600-1500 years [23].

To understand geochemical processes of REE and Hf in seawater and the processes causing the distinct Hf-Nd isotope decoupling in seawater, it is a prerequisite to understand the sources of these elements and their pathways into seawater. Rivers, aeolian dust, benthic flows, and high temperature hydrothermal fluids are potential transport media and are described in more detail below.

\section{Riverine Input}

The dissolved REE and Hf concentrations of river waters are orders of magnitude higher relative to their seawater concentrations. Dissolved REE are predominantly bound to negatively charged nanoparticles and Fe-rich (organic) colloids, which results in reciprocal repulsion and retention in solution. Significant removal of particle reactive elements occurs in the estuarine system during freshwater mixing with saline waters, even at salinity levels below $5 \%[45,46]$. During estuarine mixing processes, dissolved riverine REE are removed from the solution due to a change of the surface charge, resulting in coagulation (salting out effect) of the REE-carrying phases and a removal from the dissolved seawater pool [45-48]. REE behave almost conservative in organic-rich systems [31] and only a small percentage of the suspended particles and colloids are trapped in the estuary [31,49], while the remaining particles and colloids enter the open oceans. In marked contrast, in systems dominated by inorganic particles, REE behave non-conservatively $[31,46,47,50]$ and $>98 \%$ of the suspended material is trapped in the estuary [46,51]. Rousseau et al. [50] showed that leached particulate REE from the Amazonas river contribute significantly to the dissolved REE budget and the Nd isotopic composition of the modern oceans, indicating that riverine REE input is an important source for the global modern oceans and its Nd isotope compositions. For Hf however, Bau and Koschinsky [52] postulate from the element perspective that there should be no significant riverine Hf pathway for truly dissolved Hf 
into seawater based on the high particle reactivity and strong affinity of $\mathrm{Hf}$ to organic and inorganic colloids $[27,52,53]$ that get almost completely trapped during estuarine mixing. The impact of larger particles on the isotopic composition of $\mathrm{Hf}$ in the dissolved fraction of (ancient) seawater that are exported across the estuary into the open ocean is barely understood yet. However, a compilation of all available river water data showed that Hf-Nd decoupling in rivers results in a large $\varepsilon \mathrm{Hf}_{\text {today }}$ variability in restricted basins and that $\mathrm{Hf}-\mathrm{Nd}$ decoupling in rivers alone is not viable to explain the more homogenous $\varepsilon \mathrm{Hf}_{\text {today }}$ values in open oceans relative to those in fresh waters [30,35,54].

\section{Aeolian Input}

The importance of aeolian REE and Hf contributions to the respective dissolved and isotopic inventories of the global oceans is still under heavy debate. The dissolution process of REE from (nano)particles in the water column after episodic events of aeolian ash or dust particle input for example by Saharan winds or volcanic eruptions is suggested to contribute to the dissolved REE budget of seawater and its $\mathrm{Nd}$ isotope composition. Tachikawa et al. [55] and Greaves et al. [56] propose a significant $(\sim 20 \%)$ REE flux via partial dissolution of aeolian particles to the dissolved REE budget of the global oceans. Furthermore, Nd isotopes of the Pacific indicate that a significant amount of REE derived from volcanic ashes contributed to the dissolved seawater pool and the $\mathrm{Nd}$ isotopic composition of the ocean ([57], and references therein). In contrast, Jones et al. [58] report insignificant REE contributions of aeolian particles to the dissolved REE budget of Pacific seawater and Bayon et al. [59] even state that aeolian particles act as REE sinks rather than as source for dissolved REE in seawater. Aeolian processes are also suggested to contribute to the global seawater Hf budget. Albarède et al. [21] postulated that the distinct Hf-Nd decoupling in FeMn crusts and nodules is derived from radiogenic Hf input of fine grained, zircon-free wind-blown dust particles. Indeed, Hf-Nd isotope decoupling can be produced by dust leaching experiments that fully reproduce the Hf-Nd isotope decoupling of the 'seawater array', indicating that seawater leaching of aeolian material may be a potential mechanism to fully explain the Hf-Nd isotope decoupling in oceans $[25,54]$.

\section{Benthic Flows}

The term 'benthic flow' includes leaching and remobilization processes of trace elements via low-temperature pore fluids from terrigenous sediments on the continental shelf and slope. REE data of pore fluids are scarce due to methodical and analytical difficulties and, hence, it is still unclear if the measured REE distributions truly reflect the REE distributions of the pore fluids or depend on REE fractionation processes during complex sampling methods. The commonly observed higher element concentrations of pore waters relative to seawater are a function of depths below the sediment-seawater interface, but also may depend on redox cycling of $\mathrm{Fe}$ and the dissolution of organic compounds $[60,61]$. Jeandel [62] and Arsouze et al. [63] showed that benthic flows and even groundwaters in coastal areas [64] are a prominent REE source to the dissolved load and affect the $\mathrm{Nd}$ isotopic composition of local seawater. The majority of $\mathrm{Hf}$ is bound to $\mathrm{Fe}($ oxy)hydroxides in modern seawater [52], but Hf cycling is not influenced by redox-cycling in seawater [65]. Although some studies suggest that boundary exchange processes between sediment and seawater are plausible mechanisms to explain the radiogenic Hf isotopic composition of seawater [28,65], the sorption and dilution mechanisms behind these processes are not known. Rickli et al. [36] postulated that the small offset between dissolved $\mathrm{Hf}-\mathrm{Nd}$ river data and seawater may (similarly to $\mathrm{Nd}$ ) be explained by boundary exchange processes.

\section{Hydrothermal Input}

Hydrothermal systems that expel high-temperature hydrothermal fluids at mid ocean ridge zones or at island arcs into seawater do not have significant impact on the global REE and Hf ocean inventories and their Hf-Nd isotope compositions. High temperature hydrothermal fluids that are rich in Fe among other metals act as sink rather than as source for REE [66]. Fe(oxy)hydroxides immediately scavenge particle-reactive elements as soon as hydrothermal fluids interact with oxidized 
seawater. Although earlier studies referred Hf-Nd isotope decoupling in Fe-Mn crusts and nodules to mantle-derived Hf input into the depositional milieu of the chemical sediments [20], this idea is nowadays not favoured anymore, e.g., [22]. From the element perspective, there should not exist any pathway for truly dissolved $\mathrm{Hf}$ from hydrothermal fluids into seawater and only colloidal Hf bound to colloids and (nano)particles may pass the fluid-seawater interaction zone [52]. However, as long as no truly dissolved Hf data from high temperature hydrothermal fluids are published, the pathways of truly dissolved and dissolved Hf at hydrothermal systems cannot finally be determined. While there is no obvious pathway for REE and Hf in oxidized, fully vented modern oceans, the situation may be more complex in the predominantly anoxic Archean oceans. Several studies $[8,67,68]$ report positive chondrite-normalized Eu anomalies in Archean marine chemical sediments, indicating significant REE fluxes via submarine high-temperature hydrothermal fluids that had altered seafloor basalts into ancient seawater during peak times of magmatic activity in Earth's history [68]. These fluids carried significant amounts of mantle-derived Nd, which had strong impact on the Nd isotopic composition of Archean seawater. Hafnium is also considered to have a hydrothermal pathway into Archean seawater [9], potentially affecting the Hf isotopic compositions of global Archean oceans.

Chemically and physically weathered and eroded terrestrial material is sufficient to produce the specific Hf-Nd isotope decoupling and the 'seawater array' of modern oceans. This either implies that dissolved Hf is not quantitatively scavenged in the estuarine systems or is leached from aeolian particles and/or that benthic flows may contribute an important amount of Hf to the dissolved and truly dissolved pools of modern oceans. However, as long as Hf-leaching mechanisms from sediment in seawater are not fully understood, the isotopic composition of suspended Hf, i.e., colloidal and particle-bound $\mathrm{Hf}$, has to be negligible for the seawater Hf isotope composition based on the high particle-reactivity and short residence time of $\mathrm{Hf}$ in seawater.

\section{Decoupled Hf-Nd in Suspended and Dissolved Loads of Late Archaean Seawater}

In 2014, the Hf-Nd isotope record was comprehensively extended from the oldest so far reported Hf-Nd systematics of Cenozoic Fe-Mn nodules to 2.7 Ga back in time until the Late Archean [8]. Although analytically very challenging due to very low Hf concentrations (down to $20 \mathrm{ppb} \mathrm{Hf}$ [9]), the authors obtained Hf-Nd isotope compositions by isotope dilution technique and MC-ICPMS analyses of alternating chert and Fe-rich bands in ultra-pure BIF samples of the Temagami BIF (Canada) that are devoid of detrital contaminations. Sm-Nd as well as Lu-Hf isochron calculations of combined chert and Fe-rich bands of the Temagami BIF yield within the error the published depositional age of $2.7 \mathrm{Ga}$, suggesting that post-depositional alteration or reset of both isotope systems was negligible [8]. Hence, the Fe- and Si-rich bands of the Temagami BIF were used as reliable archives for geochemical proxies of the truly dissolved and dissolved load of Late Archean seawater and yield a decoupling of both the $\mathrm{Hf}$ and $\mathrm{Nd}$ isotope systems with homogenous $\varepsilon \mathrm{Nd}_{2.70 \mathrm{Ga}}$ around +1 and heterogeneous $\varepsilon \mathrm{Hf}_{2.70 \mathrm{Ga}}$ values between +6.8 and +24.1 (Table 1, Figure 3). This Hf-Nd isotope decoupling is consistent with the commonly observed decoupling in modern aqueous systems (Figure 1). Garcon et al. [69] reported Hf-Nd isotope compositions in even older chemical and clastic sediments from the Meso- to Palaeoarchean greenschist-facies Fig Tree Group (Barberton, South Africa) only a few years later (Table 1, Figure 3). The clastic sediments reveal a predominantly weathered mafic terrigenous component, but associated Si-rich sediments of the $3.42 \mathrm{Ga}$ old Buck Reef Chert show high $\mathrm{Lu} / \mathrm{Hf}$ ratios and $\varepsilon \mathrm{Hf}_{3.42 \mathrm{Ga}}$ values up to +29.3 at normal $\varepsilon \mathrm{Nd}_{3.42 \mathrm{Ga}}$ values. Isochron calculations of the three chert samples yield a slightly younger depositional age with $3.28 \mathrm{Ga} \pm 0.14$ for the Sm-Nd system and $3.24 \mathrm{Ga} \pm 0.27$ for the Lu-Hf isotope system that still overlap within the error with the published depositional age [69], indicating that contributions of weathered and eroded Archean cherts may account for unusual radiogenic $\varepsilon \mathrm{Hf}$ values in younger sedimentary and aqueous systems. Indeed, the findings of Blichert-Toft et al. [70] corroborate the former study with decoupled Hf-Nd isotopes in komatiitic clinopyroxenes from the Barberton stratigraphy that can only be explained by recycling of a similar chert component into the ultramafic magma. The oldest so far reported Hf-Nd isotope 
data originate from the Eoarchean Isua BIF ([71]; Table 1). Although the Sm-Nd isotope system in the analysed BIF samples of the Isua Greenstone Belt was reset and altered by up to amphibolite facies post-depositional overprints [71,72], two Isua BIF samples (Figure 3) show decoupled Hf-Nd isotopes with $\varepsilon \mathrm{Nd}_{3.7 \mathrm{Ga}}$ values between -15.9 and -4.5 as well as $\varepsilon \mathrm{Hf}_{3.7 \mathrm{Ga}}$ values between +34.1 and +68.4 . The authors conclude that either the Hf isotope system was altered and reset after deposition similarly to the $\mathrm{Nd}$ isotope system or, alternatively, that Eoarchaean seawater was already very radiogenic in its Hf isotopic composition.

Table 1. Published $\varepsilon \mathrm{Nd}_{(\mathrm{t})}$ and $\varepsilon \mathrm{Hf}_{(\mathrm{t})}$ values (epsilon notation: measured isotope ratios relative to a reference material and multiplied by 10,000 at a certain time) of Archean Banded Iron Formations (BIFs).

\begin{tabular}{|c|c|c|c|c|c|c|c|c|}
\hline Location & Age $^{1}$ & Sample & Type & $\varepsilon \mathrm{Hf}_{(\mathrm{t})}{ }^{2}$ & $\pm 2 \sigma$ & $\varepsilon \mathrm{Nd}_{(\mathrm{t})}{ }^{2}$ & $\pm 2 \sigma$ & Source \\
\hline \multirow{2}{*}{ Isua Greenstone Belt } & \multirow{2}{*}{$\sim 3.7 \mathrm{Ga}$} & 810403 & BIF & +68.4 & 0.5 & -15.9 & 0.2 & \multirow[t]{2}{*}{ [71] } \\
\hline & & 810446 & BIF & +34.1 & 0.4 & -4.5 & 0.2 & \\
\hline \multirow{3}{*}{ Barberton Greenstone Belt } & \multirow{3}{*}{$3.42 \mathrm{Ga}$} & $227.34 \mathrm{~m}$ & Black chert & +2.9 & 0.2 & +0.4 & 0.1 & \multirow[t]{3}{*}{ [69] } \\
\hline & & $227.34 \mathrm{~m}$ & Translucent chert & +29.6 & 0.3 & -2.5 & 0.1 & \\
\hline & & $402.9 \mathrm{~m}$ & Chert breccia & -98.3 & 0.4 & +0.0 & 0.1 & \\
\hline \multirow{9}{*}{ Temagami BIF } & \multirow{9}{*}{$2.7 \mathrm{Ga}$} & FUM23 & Magnetite & +9.6 & 0.4 & +1.0 & 0.1 & \multirow[t]{9}{*}{ [8] } \\
\hline & & FUM24 & Magnetite & +8.4 & 0.4 & +1.0 & 0.2 & \\
\hline & & FUM25 & Magnetite & +24.1 & 0.5 & +1.1 & 0.2 & \\
\hline & & FUM27 & Magnetite & +6.7 & 0.5 & +0.94 & 0.3 & \\
\hline & & FUM28 & Magnetite & +16.5 & 0.8 & +1.3 & 0.2 & \\
\hline & & FUM26 & Chert & +9.6 & 0.7 & +0.71 & 0.3 & \\
\hline & & FUM29 & Chert & +6.8 & 0.3 & +1.1 & 0.2 & \\
\hline & & FUM30 & Chert & +6.8 & 0.4 & +3.0 & 0.2 & \\
\hline & & FUM31 & Chert & +7.1 & 0.5 & +0.22 & 0.2 & \\
\hline \multirow{8}{*}{ Krivoy Rog BIF } & \multirow{8}{*}{$2.6 \mathrm{Ga}$} & FUM57 & Pure Fe-band & +9.5 & 1.1 & -2.3 & 0.4 & \multirow[t]{8}{*}{ [9] } \\
\hline & & FUM54 & A. pure Fe-band & -0.9 & 1.2 & -1.3 & 0.4 & \\
\hline & & FUM53 & Impure Fe-band & +1.0 & 0.7 & +0.0 & 0.4 & \\
\hline & & FUM55 & Impure Fe-band & +10.9 & 0.5 & -1.6 & 0.4 & \\
\hline & & FUM56 & Impure Fe-band & +25.9 & 0.9 & -0.4 & 0.4 & \\
\hline & & FUM58 & Impure chert & +0.1 & 0.3 & -2.3 & 0.4 & \\
\hline & & FUM59 & Impure chert & +9.1 & 0.5 & -0.8 & 0.4 & \\
\hline & & FUM60 & Impure chert & +60.6 & 1.0 & -0.9 & 0.4 & \\
\hline
\end{tabular}

${ }^{1}$ The age of individual BIF sequences corresponds to the published depositional ages in related publications; ${ }^{2}$ Initial $\varepsilon \mathrm{Nd}_{(\mathrm{t})}$ and $\varepsilon \mathrm{Hf}_{(\mathrm{t})}$ values were (re)calculated using the CHUR (chondritic uniform reservoir) parameters of [73] and the ${ }^{147} \mathrm{Sm}$ and ${ }^{176} \mathrm{Lu}$ decay constants of [74-76].

Pure marine chemical sediments tap the truly dissolved and maybe the dissolved loads of the fluids from which they were precipitated. While only few Hf-Nd data of pure marine chemical sediments exist from Archean times, Viehmann et al. [9] reported Hf-Nd isotopes of pure BIFs (truly dissolved plus dissolved loads) and of detritus-contaminated BIFs (dissolved load plus fine grained suspended material) from the Late Archean Krivoy Rog BIF. The pure BIF samples corroborate the Hf-Nd decoupling in Late Archean seawater that was also reported for the near-contemporaneous Late Archean Temagami BIF [8]. Although there may be potential hydrothermal Hf pathways into Archean seawater similar to the REE $[9,68]$, the $\varepsilon \mathrm{Hf}_{2.70 \mathrm{Ga}}$ values of the Temagami BIFs are more radiogenic relative to the most positive $\varepsilon \mathrm{Hf}_{2.70 \mathrm{Ga}}$ value of mantle-derived rocks from the Abitibi Greenstone Belt, suggesting that not only hydrothermal $\mathrm{Hf}$ was responsible to decouple the Hf-Nd isotopes in Late Archean seawater, but also another process was needed to produce the radiogenic $\varepsilon \mathrm{Hf}_{2.70 \mathrm{Ga}}$ signature of Temagami seawater [8]. Hence, the very radiogenic Hf signature at two near-contemporaneous Late Archean BIF localities can only be explained by incongruent Hf weathering of emerged zircon-bearing uppermost continental crust and implies that Hf-Nd decoupling in Late Archean seawater was rather a global than a local phenomenon. Furthermore, the detritus-contaminated Krivoy Rog BIF samples also show decoupled Hf-Nd isotopes with slightly more positive $\varepsilon \mathrm{Nd}_{2.60 \mathrm{Ga}}$ and far more radiogenic $\varepsilon \mathrm{Hf}_{2.60 \mathrm{Ga}}$ values up to +60.6 relative to the pure chemical sediment endmember (Figure 3 ). These findings suggest that mineral sorting processes on Late Archean continents and oceans played an important role to decouple $\mathrm{Hf}$ and $\mathrm{Nd}$ isotopes in Archean sedimentary systems, assuming that 
weathering and erosion processes such as aeolian and riverine sediment transports were almost similar to those observed in the modern environments.

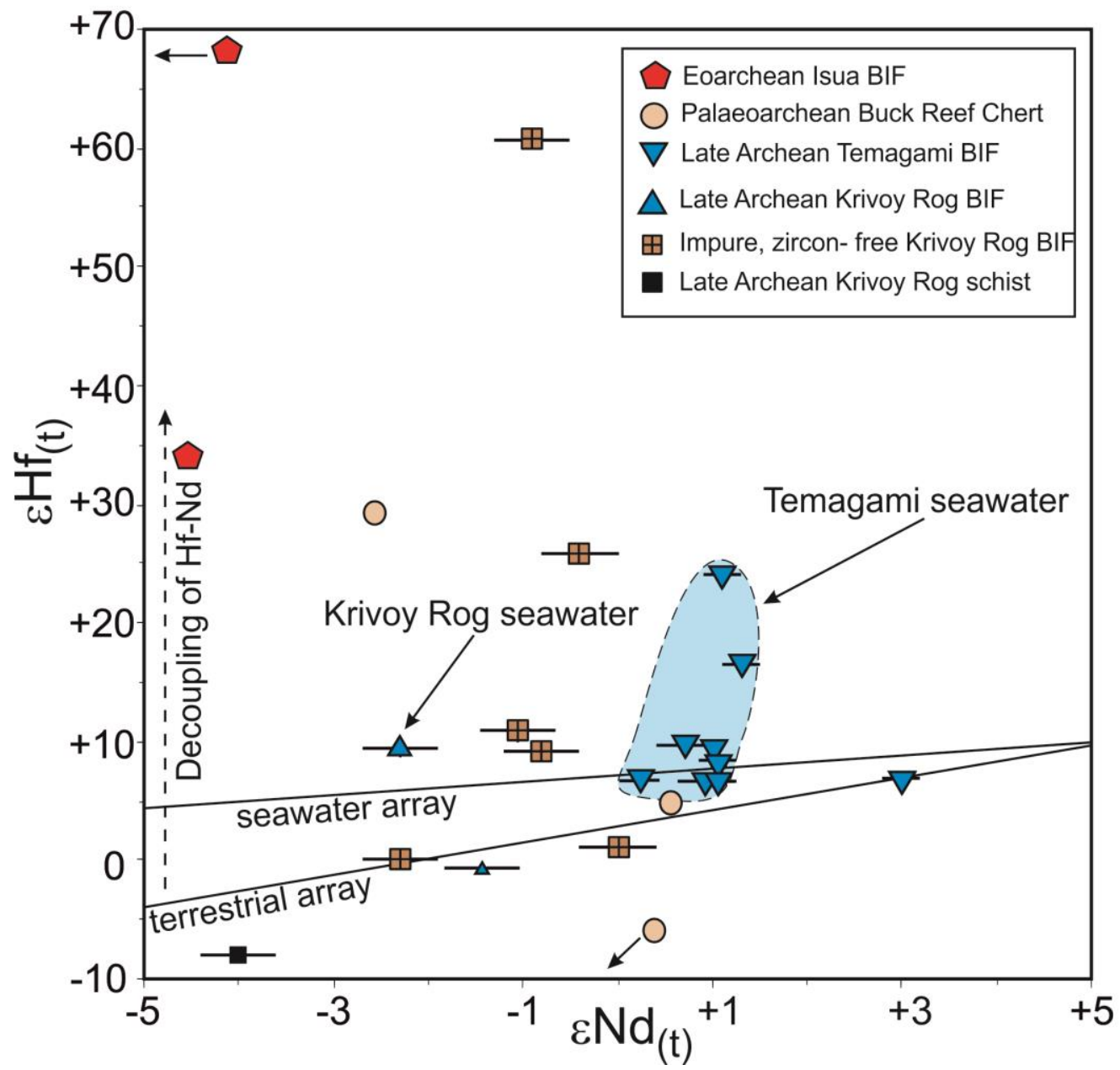

Figure 3. Initial $\varepsilon \mathrm{Nd}_{(\mathrm{t})}$ and $\varepsilon \mathrm{Hf}_{(\mathrm{t})}$ values of Eo-, Meso-, and Neoarchean Banded Iron Formations (BIFs) relative to the seawater and terrestrial arrays and a Krivoy Rog schist. The Hf-Nd isotope systems were already decoupled in the suspended and dissolved fractions of global Late Archean seawater and potentially on local scales during the Meso- and Eoarchean, indicating that emerged, zircon-bearing upper continental crust was available for subaerial weathering and erosion to eventually decouple the Hf-Nd isotopes in the suspended and (truly) dissolved loads of Archean oceans. Data are taken from $[8,9,17,21,69,71]$. Errors are $2 \sigma$ and may be smaller than the symbol size.

\section{Implications for the Geodynamical Evolution of Archaean Continents and Their Impact on the Earliest Marine Habitats}

Coupled Hf-Nd isotope systematics in aqueous environments have been shown to be a powerful tool to investigate weathering and erosion processes on modern continents. Applying this novel geochemical proxy to Archean samples opens the unique opportunity to not only trace weathering and erosion processes of the earliest uppermost continents, but also indirectly unravels the geodynamical evolution of Archean continents and the combined nutrient fluxes into the earliest marine habitats on Earth. Archean continental crust is predominantly mafic to ultramafic in composition and the uppermost continental levels consist of stacked basaltic lithologies and oceanic plateaus with abundant TTGs in middle to lower crustal levels that have episodically been brought to the uppermost continental levels via gravitational overturns $[1,13]$. Hence, Archean continents were predominantly submerged and the uppermost continental crust was mostly covered by oceans and not available for 
subaerial weathering and erosion processes [5]. Indeed, Kamber [6] showed that weathered mafic to ultramafic continental crust is needed to reproduce the typical REE patterns of Archean marine chemical sediments.

A recent study showed a decoupling of the Hf-Nd isotope systems in Late Archean BIFs that is similar to decoupling of the Hf-Nd systems in modern and Cenozoic seawater [8]. The findings suggest that incongruent Hf weathering of emerged continents occurred in the Late Archean with the prerequisite that the uppermost continental crust was evolved and had to be available for subaerial weathering and erosion processes already $2.7 \mathrm{Ga}$ ago. Incongruent Hf weathering of more evolved uppermost continental crust and the significance of the 'zircon effect' during Late Archean times was later corroborated by an additional Hf-Nd isotope study of pure and detritus-contaminated BIFs [9] and by a comprehensive trace element study of shales [7]. These studies confirmed a shift in the trace element composition of weathered uppermost continental crust from (ultra)mafic to more felsic at $2.7 \mathrm{Ga}$. Furthermore, Wiemer et al. [13] showed that dense (ultra)mafic stacks and underlying felsic proto-continental crust in the ca. 3.4 Ga old Pilbara Craton was reorganized via gravitation overturns, allowing felsic continental crust to reach the uppermost continental levels and be available for subaerial weathering and erosion processes. Because Hf-Nd isotope decoupling was observed in BIFs at two near-contemporaneous localities [8,9], Hf-Nd decoupling can be considered rather as a global than a local phenomenon in Late Archean oceans [9] and it is now important to further step back in time and pinpoint the timing of which more evolved continental crust had impact on the local, but also global seawater chemistry, because Palaeo- to Mesoarchean greenstone belt succession contain rare siliciclastic intercalations that give sedimentological and geochemical evidence for weathered and eroded evolved continental material [10-12]. For instance, a small data set of decoupled Hf and $\mathrm{Nd}$ isotopes are reported in marine chemical sediments from the 3.4 Ga old Barberton [69] and 3.7 Ga old Isua Greenstone Belts [71], indicating that incongruent Hf weathering of more evolved material potentially already had impact on local ancient seawater already during the Palaeo- and Eoarchean.

The composition of the weathered and eroded material of the uppermost continental crust not only has huge implications on the geodynamical evolution of Archean cratons and the interplay between the mantle and crust, but also for the earliest marine habitats on Earth. Weathering of (ultra)mafic uppermost continental crust provides orders of magnitude higher nutrient fluxes of elements that are suggested to be (micro)nutrients (e.g., $\mathrm{Fe}, \mathrm{P}, \mathrm{Ni}, \mathrm{Cr}, \mathrm{Co}, \mathrm{Cu}, \mathrm{Se}, \mathrm{Mn}$, and $\mathrm{Zn}$ [7]) and are cornerstones for the evolution and establishment of the earliest microbial life on Earth. Although Hf and REE are not necessarily known to be important nutrients, coupled Hf-Nd isotopes may provide unique information about the weathered and eroded material of the uppermost continental levels and the nutrient flux into ambient seawater. Following the approach of a previous paper [7], weathering of more evolved continental material decreased the habitability of shallow marine environments after $2.7 \mathrm{Ga}$. However, the urgent questions remain (I) to which amount clastic material that was weathered and eroded from more evolved continental crust had direct impact on the dissolved and truly dissolved loads of ancient seawater chemistry and (II) if weathering of evolved continental crust affected seawater chemistry only on local or even on global scales. A first study showed in accordance to REE [68] that there potentially existed a hydrothermal Hf pathway into Late Archean oceans [9], which is in contrast to the modern environment [66]. Hydrothermal fluids are suggested to be important building blocks for the origin of life $[77,78]$ and had strong impacts on Archean seawater chemistry during peak episodes of magmatic activity during Archean times [68]. If true, high temperature hydrothermal fluids may be an additional important source to provide nutrients among other elements that are limited by weathering of more evolved continental crust into the earliest microbial habitats on Earth.

\section{Summary}

Coupled Hf-Nd isotope systematics in modern to Cenozoic aqueous systems have been shown to be powerful geochemical proxies to investigate weathering and erosion processes on the continental hinterland. While Hf-Nd isotopes are coupled in magmatic systems, incongruent Hf weathering of 
the continental crust and the 'zircon effect' led to decoupling of both isotope systems in the (truly) dissolved loads of fresh waters and seawater as well as between coarse-grained and fine-grained sediments. The use of this novel geochemical application in Archean marine chemical sediments reveals a similar decoupling of both isotope systems in the dissolved and suspended fractions of Late Archean seawater and in Palaeoarchean and even Eoarchean marine chemical sediments. Contrary to the commonly accepted view that the uppermost continental crust was predominantly (ultra)mafic in their composition and due to lower buoyancy submerged, at latest at 2.7 Ga significant amounts of more evolved, emerged continental material was available for weathering and erosion processes and had significant impact on local and global seawater chemistry. Different chemical compositions of the uppermost continental crust had major impact on the nutrient influx delivered by the continental hinterland into the earliest marine habitats on Earth. However, only few coupled Hf-Nd data sets of Archean marine chemical sediments exist yet and Hf-Nd geochemistry in marine chemical sediments have shown to be a unique geochemical tool that can be used in future research to unravel the geodynamical evolution of Early Earth, gather insights into weathering and erosion processes on the earliest emerged continents and the composition of the uppermost continental crust, as well as the nutrient flux from the continents that directly affected the earliest marine habitats on Earth.

Funding: This project and the open access costs are funded from the European Union's Horizon 2020 research and innovation program of the Marie Sklodowska-Curie grant agreement No. 746033 for project ELEMIN.

Acknowledgments: The author acknowledges J. Elis Hoffmann, Lisa Baldwin, and Simon V. Hohl for discussions and improvement of the first version of the manuscript and two anonymous reviewers for their detailed and helpful reviews that improved the final version of this manuscript.

Conflicts of Interest: The author declares no conflicts of interest.

\section{References}

1. Kamber, B.S. The evolving nature of terrestrial crust from the Hadean, through the Archaean, into the Proterozoic. Precambrian Res. 2015, 258, 48-82. [CrossRef]

2. Hoffmann, J.E.; Zhang, C.; Moyen, J.-F.; Nagel, T. The formation of tonalites-trondjhemites-granodiorites and of the early continental crust. In Earth's Oldest Rocks, 2nd ed.; van Kranendonk, M., Bennett, V., Hoffmann, J.E., Eds.; Elsevier: Amsterdam, The Netherlands, 2018; ISBN 9780444639011.

3. Hoffmann, J.E.; Münker, C.; Næraa, T.; Rosing, M.T.; Herwartz, D.; Garbe-Schönberg, D.; Svahnberg, H. Mechanisms of Archean crust formation inferred from high-precision HFSE systematics in TTGs. Geochim. Cosmochim. Acta 2011, 75, 4157-4178. [CrossRef]

4. Arndt, N.T. Formation and Evolution of the Continental Crust. Geochem. Perspect. Lett. 2013, 2, 405-533. [CrossRef]

5. Flament, N.; Coltice, N.; Rey, P.F. A case for late-Archaean continental emergence from thermal evolution models and hypsometry. Earth Planet. Sci. Lett. 2008, 275, 326-336. [CrossRef]

6. Kamber, B.S. Archean mafic-ultramafic volcanic landmasses and their effect on ocean-atmosphere chemistry. Chem. Geol. 2010, 274, 19-28. [CrossRef]

7. Large, R.R.; Mukherjee, I.; Zhukova, I.; Corkrey, R.; Stepanov, A.; Danyushevsky, L.V. Role of upper-most crustal composition in the evolution of the Precambrian ocean-atmosphere system. Earth Planet. Sci. Lett. 2018, 487, 44-53. [CrossRef]

8. Viehmann, S.; Hoffmann, J.E.; Münker, C.; Bau, M. Decoupled Hf-Nd isotopes in Neoarchean seawater reveal weathering of emerged continents. Geology 2014, 42, 115-118. [CrossRef]

9. Viehmann, S.; Bau, M.; Hoffmann, J.E.; Münker, C. Decoupled Hf and Nd isotopes in suspended particles and in the dissolved load of Late Archean seawater. Chem. Geol. 2018, 483, 111-118. [CrossRef]

10. van Kranendonk, M.J.; Hickman, A.H.; Smithes, R.H.; Nelson, D.R. Geology and tectonic evolution of the Archean North Pilbara Terrain, Pilbara Craton, Western Australia. Econ. Geol. 2002, 97, 695-732. [CrossRef]

11. Heubeck, C.; Engelhardt, J.; Byerly, G.R.; Zeh, A.; Sell, B.; Luber, T.; Lowe, D.R. Timing of deposition and deformation of the Moodies Group (Barberton Greenstone Belt, South Africa): Very-high-resolution of Archaean surface processes. Precambrian Res. 2013, 231, 236-262. [CrossRef] 
12. Smith, A.J.B.; Beukes, N.J.; Gutzmer, J. The composition and depositional environments of Mesoarchean iron formations of the West Rand Group of the Witwatersrand Supergroup, South Africa. Econ. Geol. 2013, 108, 111-134. [CrossRef]

13. Wiemer, D.; Schrank, C.E.; Murphy, D.T.; Wenham, L.; Allen, C.M. Earth's oldest stable crust in the Pilbara Craton formed by cyclic gravitational overturns. Nat. Geosci. 2018. [CrossRef]

14. Szilas, K.; Hoffmann, J.E.; Hansmeier, C.; Hollis, J.A.; Münker, C.; Viehmann, S.; Kasper, H.U. Sm-Nd and Lu-Hf isotope and trace-element systematics of Mesoarchaean amphibolites, inner Ameralik fjord, southern West Greenland. Mineral. Mag. 2015, 79, 857-876. [CrossRef]

15. Szilas, K.; Hoffmann, J.E.; Schulz, T.; Hansmeier, C.; Polat, A.; Viehmann, S.; Kasper, H.U.; Münker, C. Combined bulk-rock Hf- and Nd-isotope compositions of Mesoarchaean metavolcanic rocks from the Ivisaartoq Supracrustal Belt, SW Greenland: Deviations from the mantle array caused by crustal recycling. Chemie der Erde Geochemistry 2016, 76, 543-554. [CrossRef]

16. Hoffmann, J.E.; Kröner, A.; Hegner, E.; Viehmann, S.; Xie, H.; Iaccheri, L.M.; Schneider, K.P.; Hofmann, A.; Wong, J.; Geng, H.; et al. Source composition, fractional crystallization and magma mixing processes in the 3.48-3.43 Ga Tsawela tonalite suite (Ancient Gneiss Complex, Swaziland)—Implications for Palaeoarchaean geodynamics. Precambrian Res. 2016, 276, 43-66. [CrossRef]

17. Vervoort, J.D.; Patchett, P.J.; Blichert-Toft, J.; Albarède, F. Relationships between Lu-Hf and Sm-Nd isotopic systems in the global sedimentary system. Earth Planet. Sci. Lett. 1999, 168, 79-99. [CrossRef]

18. Piepgras, D.J.; Wasserburg, G.J. Neodymium isotopic variations in seawater. Earth Planet. Sci. Lett. 1980, 50, 128-138. [CrossRef]

19. Rickli, J.; Frank, M.; Halliday, A.N. The hafnium-neodymium isotopic composition of Atlantic seawater. Earth Planet. Sci. Lett. 2009, 280, 118-127. [CrossRef]

20. White, W.M.; Patchett, J.; Ben Othman, D. Hf isotope ratios of marine sediments and Mn nodules: Evidence for a mantle source of Hf in seawater. Earth Planet. Sci. Lett. 1986, 79, 46-54. [CrossRef]

21. Albarède, F.; Simonetti, A.; Vervoort, J.D.; Blichert-Toft, J.; Abouchami, W. A Hf-Nd isotopic correlation in ferromanganese nodules. Geophys. Res. Lett. 1998, 25, 3895-3898. [CrossRef]

22. van de Flierdt, T.; Goldstein, S.L.; Hemming, S.R.; Roy, M.; Frank, M.; Halliday, A.N. Global neodymium-hafnium isotope systematics-revisited. Earth Planet. Sci. Lett. 2007, 259, 432-441. [CrossRef]

23. Godfrey, L.V.; Zimmermann, B.; Lee, D.C.; King, R.L.; Vervoort, J.D.; Sherrell, R.M.; Halliday, A.N. Hafnium and neodymium isotope variations in NE Atlantic seawater. Geochem. Geophys. Geosyst. 2009, 10, 1-13. [CrossRef]

24. Zimmermann, B.; Porcelli, D.; Frank, M.; Rickli, J.; Lee, D.C.; Halliday, A.N. The hafnium isotope composition of Pacific Ocean water. Geochim. Cosmochim. Acta 2009, 73, 91-101. [CrossRef]

25. Pettke, T.; Lee, D.C.; Halliday, A.N.; Rea, D.K. Radiogenic Hf isotopic compositions of continental eolian dust from Asia, its variability and its implications for seawater Hf. Earth Planet. Sci. Lett. 2002, 202, $453-464$. [CrossRef]

26. Bayon, G.; Vigier, N.; Burton, K.W.; Brenot, A.; Carignan, J.; Etoubleau, J.; Chu, N.C. The control of weathering processes on riverine and seawater hafnium isotope ratios. Geology 2006, 34, 433-436. [CrossRef]

27. Rickli, J.; Frank, M.; Stichel, T.; Georg, R.B.; Vance, D.; Halliday, A.N. Controls on the incongruent release of hafnium during weathering of metamorphic and sedimentary catchments. Geochim. Cosmochim. Acta 2013, 101, 263-284. [CrossRef]

28. Rickli, J.; Gutjahr, M.; Vance, D.; Fischer-Gödde, M.; Hillenbrand, C.D.; Kuhn, G. Neodymium and hafnium boundary contributions to seawater along the West Antarctic continental margin. Earth Planet. Sci. Lett. 2014, 394, 99-110. [CrossRef]

29. Bayon, G.; Skonieczny, C.; Delvigne, C.; Toucanne, S.; Bermell, S.; Ponzevera, E.; André, L. Environmental Hf-Nd isotopic decoupling in World river clays. Earth Planet. Sci. Lett. 2016, 438, 25-36. [CrossRef]

30. Filippova, A.; Frank, M.; Kienast, M.; Rickli, J.; Hathorne, E.; Yashayaev, I.M.; Pahnke, K. Water mass circulation and weathering inputs in the Labrador Sea based on coupled Hf-Nd isotope compositions and rare earth element distributions. Geochim. Cosmochim. Acta 2017, 199, 164-184. [CrossRef]

31. Merschel, G.; Bau, M.; Schmidt, K.; Münker, C.; Dantas, E.L. Hafnium and neodymium isotopes and REY distribution in the truly dissolved, nanoparticulate/colloidal and suspended loads of rivers in the Amazon Basin, Brazil. Geochim. Cosmochim. Acta 2017, 213, 383-399. [CrossRef] 
32. Patchett, P.J.; White, W.M.; Feldmann, H.; Kielinczuk, S.; Hofmann, A.W. Hafnium/rare earth element fractionation in the sedimentary system and crustal recycling into the Earth's mantle. Earth Planet. Sci. Lett. 1984, 69, 365-378. [CrossRef]

33. Garçon, M.; Chauvel, C. Where is basalt in river sediments, and why does it matter? Earth Planet. Sci. Lett. 2014, 407, 61-69. [CrossRef]

34. Bayon, G.; Toucanne, S.; Skonieczny, C.; André, L.; Bermell, S.; Cheron, S.; Dennielou, B.; Etoubleau, J.; Freslon, N.; Gauchery, T.; et al. Rare earth elements and neodymium isotopes in world river sediments revisited. Geochim. Cosmochim. Acta 2015, 170, 17-38. [CrossRef]

35. Gutjahr, M.; Frank, M.; Lippold, J.; Halliday, A.N. Peak Last Glacial weathering intensity on the North American continent recorded by the authigenic Hf isotope composition of North Atlantic deep-sea sediments. Quat. Sci. Rev. 2014, 99, 97-117. [CrossRef]

36. Rickli, J.; Hindshaw, R.S.; Leuthold, J.; Wadham, J.L.; Burton, K.W.; Vance, D. Impact of glacial activity on the weathering of Hf isotopes-Observations from Southwest Greenland. Geochim. Cosmochim. Acta 2017, 215, 295-316. [CrossRef]

37. Chen, T.Y.; Ling, H.F.; Frank, M.; Zhao, K.D.; Jiang, S.Y. Zircon effect alone insufficient to generate seawater Nd-Hf isotope relationships. Geochem. Geophys. Geosyst. 2011, 12, 1-9. [CrossRef]

38. Garçon, M.; Chauvel, C.; France-Lanord, C.; Huyghe, P.; Lavé, J.Ô. Continental sedimentary processes decouple $\mathrm{Nd}$ and Hf isotopes. Geochim. Cosmochim. Acta 2013, 121, 177-195. [CrossRef]

39. Vervoort, J.D.; Plank, T.; Prytulak, J. The Hf-Nd isotopic composition of marine sediments. Geochim. Cosmochim. Acta 2011, 75, 5903-5926. [CrossRef]

40. Broecker, W.S.; Peng, T.H. Tracers in the Sea; Eldigio Press: New York, NY, USA, 1982.

41. Tachikawa, K.; Athias, V.; Jeandel, C. Neodymium budget in the modern ocean and paleo-oceanographic implications. J. Geophys. Res. 2003, 108, 3254. [CrossRef]

42. Rempfer, J.; Stocker, T.F.; Joos, F.; Dutay, J.C.; Siddall, M. Modelling Nd-isotopes with a coarse resolution ocean circulation model: Sensitivities to model parameters and source/sink distributions. Geochim. Cosmochim. Acta 2011, 75, 5927-5950. [CrossRef]

43. Godfrey, L.V.; White, W.M.; Salters, V.J.M. Dissolved zirconium and hafnium distributions across a shelf break in the northeastern Atlantic Ocean. Geochim. Cosmochim. Acta 1996, 60, 3995-4006. [CrossRef]

44. Rickli, J.; Frank, M.; Baker, A.R.; Aciego, S.; de Souza, G.; Georg, R.B.; Halliday, A.N. Hafnium and neodymium isotopes in surface waters of the eastern Atlantic Ocean: Implications for sources and inputs of trace metals to the ocean. Geochim. Cosmochim. Acta 2010, 74, 540-557. [CrossRef]

45. Elderfield, H.; Upstill-Goddard, R.; Sholkovitz, E.R. The rare earth elements in rivers, estuaries, and coastal seas and their significance to the composition of ocean waters. Geochim. Cosmochim. Acta 1990, 54, 971-991. [CrossRef]

46. Tepe, N.; Bau, M. Behavior of rare earth elements and yttrium during simulation of arctic estuarine mixing between glacial-fed river waters and seawater and the impact of inorganic (nano-)particles. Chem. Geol. 2016, 438, 134-145. [CrossRef]

47. Sholkovitz, E.R. The geochemistry of rare earth elements in the Amazon River estuary. Geochim. Cosmochim. Acta 1993, 57, 2181-2190. [CrossRef]

48. Lawrence, M.G.; Kamber, B.S. The behaviour of the rare earth elements during estuarine mixing-revisited. Mar. Chem. 2006, 100, 147-161. [CrossRef]

49. Boyle, E.A.; Edmond, J.M.; Sholkovitz, E.R. The mechanism of iron removal in estuaries. Geochim. Cosmochim. Acta 1977, 41, 1313-1324. [CrossRef]

50. Rousseau, T.C.C.; Sonke, J.E.; Chmeleff, J.; Van Beek, P.; Souhaut, M.; Boaventura, G.; Seyler, P.; Jeandel, C. Rapid neodymium release to marine waters from lithogenic sediments in the Amazon estuary. Nat. Commun. 2015, 6, 7592. [CrossRef] [PubMed]

51. Pokrovsky, O.S.; Shirokova, L.S.; Viers, J.; Gordeev, V.V.; Shevchenko, V.P.; Chupakov, A.V.; Vorobieva, T.Y.; Candaudap, F.; Causserand, C.; Lanzanova, A.; et al. Fate of colloids during estuarine mixing in the Arctic. Ocean Sci. 2014, 10, 107-125. [CrossRef]

52. Bau, M.; Koschinsky, A. Hafnium and neodymium isotopes in seawater and in ferromanganese crusts: The "element perspective". Earth Planet. Sci. Lett. 2006, 241, 952-961. [CrossRef] 
53. Ingri, J.; Widerlund, A.; Land, M.; Gustafsson, Ö.; Andersson, P.; Öhlander, B. Temporal variations in the fractionation of the rare earth elements in a Boreal river; the role of colloidal particles. Chem. Geol. 2000, 166, 23-45. [CrossRef]

54. Chen, T.Y.; Li, G.; Frank, M.; Ling, H.F. Hafnium isotope fractionation during continental weathering: Implications for the generation of the seawater Nd-Hf isotope relationships. Geophys. Res. Lett. 2013, 40, 916-920. [CrossRef]

55. Tachikawa, K.; Jeandel, C.; Roy-Barman, M. A new approach to the Nd residence time in the ocean: The role of atmospheric inputs. Earth Planet. Sci. Lett. 1999, 170, 433-446. [CrossRef]

56. Greaves, M.; Elderfield, H.; Sholkovitz, E. Aeolian sources of rare earth elements to the Western Pacific Ocean. Mar. Chem. 1999, 68, 31-38. [CrossRef]

57. Goldstein, S.; Hemming, S. Long-lived isotopic tracers in oceanography, paleooceanography, and ice-sheet dynamics. In Treatise of Geochemistry; Elderfield, H., Holland, H.D., Turekian, K.K., Eds.; Elsevier: New York, NY, USA, 2003; Volume 6, ISBN 0-08-043751-6.

58. Jones, C.E.; Halliday, A.N.; Rea, D.K.; Owen, R.M. Neodymium isotopic variations in North Pacific modern silicate sediment and the insignificance of detrital REE contributions to seawater. Earth Planet. Sci. Lett. 1994, 127, 55-66. [CrossRef]

59. Bayon, G.; German, C.R.; Burton, K.W.; Nesbitt, R.W.; Rogers, N. Sedimentary Fe-Mn oxyhydroxides as paleoceanographic archives and the role of aeolian flux in regulating oceanic dissolved REE. Earth Planet. Sci. Lett. 2004, 224, 477-492. [CrossRef]

60. Elderfield, H.; Sholkovitz, E.R.R. Rare earth elements in the pore waters of reducing nearshore sediments. Earth Planet. Sci. Lett. 1987, 82, 280-288. [CrossRef]

61. Haley, B.A.; Klinkhammer, G.P.; McManus, J. Rare earth elements in pore waters of marine sediments. Geochim. Cosmochim. Acta 2004, 68, 1265-1279. [CrossRef]

62. Jeandel, C.; Arsouze, T.; Lacan, F.; Téchiné, P.; Dutay, J.C. Isotopic Nd compositions and concentrations of the lithogenic inputs into the ocean: A compilation, with an emphasis on the margins. Chem. Geol. 2007, 239, 156-164. [CrossRef]

63. Arsouze, T.; Dutay, J.C.; Lacan, F.; Jeandel, C. Modeling the neodymium isotopic composition with a global ocean circulation model. Chem. Geol. 2007, 239, 165-177. [CrossRef]

64. Johannesson, K.H.; Palmore, C.D.; Fackrell, J.; Prouty, N.G.; Swarzenski, P.W.; Chevis, D.A.; Telfeyan, K.; White, C.D.; Burdige, D.J. ScienceDirect Rare earth element behavior during groundwater-Seawater mixing along the Kona Coast of Hawaii. Geochim. Cosmochim. Acta 2017, 198, 229-258. [CrossRef]

65. Chen, T.Y.; Stumpf, R.; Frank, M.; Bełdowski, J.; Staubwasser, M. Contrasting geochemical cycling of hafnium and neodymium in the central Baltic Sea. Geochim. Cosmochim. Acta 2013, 123, 166-180. [CrossRef]

66. German, C.R.; Klinkhammer, G.P.; Edmond, J.M.; Mitra, A.; Elderfield, H. Hydrothermal scavenging of rare earth elements in the ocean. Nature 1990, 345, 516-518. [CrossRef]

67. Danielson, A.; Möller, P.; Dulski, P. The europium anomalies in banded iron formations and the thermal history of the oceanic crust. Chem. Geol. 1992, 97, 89-100. [CrossRef]

68. Viehmann, S.; Bau, M.; Hoffmann, J.E.; Münker, C. Geochemistry of the Krivoy Rog Banded Iron Formation, Ukraine, and the impact of peak episodes of increased global magmatic activity on the trace element composition of Precambrian seawater. Precambrian Res. 2015, 270. [CrossRef]

69. Garçon, M.; Carlson, R.W.; Shirey, S.B.; Arndt, N.T.; Horan, M.F.; Mock, T.D. Erosion of Archean continents: The Sm-Nd and Lu-Hf isotopic record of Barberton sedimentary rocks. Geochim. Cosmochim. Acta 2017, 206, 216-235. [CrossRef]

70. Blichert-Toft, J.; Arndt, N.T.; Wilson, A.; Coetzee, G. Hf and Nd isotope systematics of early Archean komatiites from surface sampling and ICDP drilling in the Barberton Greenstone Belt, South Africa. Am. Mineral. 2015, 100, 2396-2411. [CrossRef]

71. Blichert-Toft, J.; Albarède, F.; Rosing, M.; Frei, R.; Bridgwater, D. The Nd and Hf isotopic evolution of the mantle through the Archean. results from the Isua supracrustals, West Greenland, and from the Birimian terranes of West Africa. Geochim. Cosmochim. Acta 1999, 63, 3901-3914. [CrossRef]

72. Shimizu, H.; Umemoto, N.; Masuda, A.; Appel, P.W.U. Sources of iron-formations in the archean isua and malene supracrustals, West Greenland: Evidence from La-Ce and Sm-Nd isotopic data and REE abundances. Geochim. Cosmochim. Acta 1990, 54, 1147-1154. [CrossRef] 
73. Bouvier, A.; Vervoort, J.D.; Patchett, P.J. The Lu-Hf and Sm-Nd isotopic composition of CHUR: Constraints from unequilibrated chondrites and implications for the bulk composition of terrestrial planets. Earth Planet. Sci. Lett. 2008, 273, 48-57. [CrossRef]

74. Lugmair, G.W.; Marti, K. Lunar initial 143Nd/144Nd: Differential evolution of the lunar crust and mantle. Earth Planet. Sci. Lett. 1978, 39, 349-357. [CrossRef]

75. Scherer, E.; Münker, C.; Mezger, K. Calibration of the Lutetium-Hafnium Clock. Science 2001, $293,683-687$. [CrossRef] [PubMed]

76. Söderlund, U.; Patchett, P.J.; Vervoort, J.D.; Isachsen, C.E. The 176Lu decay constant determined by Lu-Hf and U-Pb isotope systematics of Precambrian mafic intrusions. Earth Planet. Sci. Lett. 2004, 219, 311-324. [CrossRef]

77. Martin, W.; Baross, J.; Kelley, D.; Russell, M.J. Hydrothermal vents and the origin of life. Nat. Rev. Microbiol. 2008, 6, 805-814. [CrossRef] [PubMed]

78. Weiss, M.C.; Sousa, F.L.; Mrnjavac, N.; Neukirchen, S.; Roettger, M.; Nelson-Sathi, S.; Martin, W.F. The physiology and habitat of the last universal common ancestor. Nat. Microbiol. 2016, 1, 1-8. [CrossRef] [PubMed]

(C) 2018 by the author. Licensee MDPI, Basel, Switzerland. This article is an open access article distributed under the terms and conditions of the Creative Commons Attribution (CC BY) license (http:/ / creativecommons.org/licenses/by/4.0/). 